\title{
Bioactive Substances of Some Herbals and Their Effectiveness as Antioxidant, Antibacteria and Antifungi
}

\author{
Sinurat AP, Wina E, Rakhmani SIW, Wardhani T, Haryati T, Purwadaria T \\ Indonesian Research Institue of Animal Production \\ E-mail: arnoldsinurat@pertanian.go.id
}

(received 06-12-2017; revised 20-01-2017; accepted 15-02-2018)

\begin{abstract}
ABSTRAK
Sinurat AP, Wina E, Rakhmani SIW, Wardhani T, Haryati T, Purwadaria T. 2018. Zat bioaktif dari beberapa tanaman herbal dan keefektifannya sebagai antioksidan, antibakteri dan antijamur. JITV 23(1): 18-27. DOI: http://dx.doi.org/10.14334/jitv.v23i1.1660

Penelitian dilakukan untuk mengetahui zat bioaktif dari beberapa tanaman lokal dan keefektifannya sebagai antioksidan, antibakteri dan antiamur untuk digunakan sebagai imbuhan pakan, Sebanyak 12 tanaman digunakan dalam penelitian ini. Pengujian dilakukan terhadap kandungan total fenol, tanin dan saponin dalam ekstrak tanaman. Ekstrak tanaman juga diuji aktifitas antioksidan dan kemampuan untuk menekan produksi gas mikroba dari usus ayam secara in vitro, kemampuan untuk menghambat pertumbuhan bakteri (E.coli, S. enteritidis) dan jamur (A. niger). Hasil penelitian menunjukkan bahwa kandungan total fenol tanin tertinggi diperoleh pada ekstrak daun cengkeh, sementara kandungan saponin tetinggi diperoleh pada ekstrak daging buah Sapindus rarak. Aktifitas antioksidan tertinggi terdapat pada ekstrak daun meniran. Gas yang diproduksi oleh mikroba menurun seperti daya kerja antibiotik, dengan menambahkan pakan dengan daun meniran yang diekstraksi dengan hexan, biji kapok atau kulit buah manggis atau daun cengkeh yang diekstraksi dengan metanol. Efek inhibitor terhadap jamur diperoleh dari ekstrak daun cengkeh. Efek penghambat terbaik terhadap pertumbuhan E. coli (diukur dengan zona terang), ditemukan pada ekstrak metanol daging buah S. rarak. Penghambat yang paling efektif terhadap pertumbuhan E. coli dan salmonella adalah asap cair kulit kacang mete. Ekstrak daun cengkeh (antijamur), asap cair kulit kacang mete (antibakteri), daun meniran (antioksidan) mempunyai potensi untuk digunakan sebagai imbuhan pakan sebagai pengganti antibiotic-growth promoter.
\end{abstract}

Kata Kunci: Zat Bioaktif, Herbal, Antioksidan, Antibakteri, Antijamur

\section{ABSTRACT}

Sinurat AP, Wina E, Rakhmani SIW, Wardhani T, Haryati T, Purwadaria T. 2018. Bioactive substances of some herbals and their effectiveness as antioxidant, antibacteria and antifungi. JITV 23(1): 18-27. DOI: http://dx.doi.org/10.14334/jitv.v23i1.1660

A study was conducted to explore the bioactive substances of some local plants in order to find their effectiveness as antioxidant, antibacteria and antifungi to be used as feed additives. Twelve plants material were used in this study. The total phenol, tannin and saponin contents in the plant extract were assayed. The extracts were also assayed on their antioxidant activities and on their ability to depress in vitro gas production of microbes obtained from chicken's guts, their ability to inhibit growth of bacteria (E. coli and Salmonella enteridis) and fungi (A. niger). The results showed that the highest total phenol and total tannin contents were found in clove leaf extract, while the highest saponin content was found in Sapindus rarak fruit pericarp. The highest antioxidant activity was found in the leaffruit extract. Gas produced by microorganims was reduced to the level similar to antibiotic addition were found with addition of hexane- extract of leaffruit, kapok seed or methanol- extract of mangosteen fruit rind pulp or clove leaves. The best inhibitory effect on E. coli growth (measured by clearing zone) was found in methanol extract of S. rarak fruit. However, the most effective growth inhibitor for both E. coli and Salmonella was the liquid smoke of cashew nut shell. The best growth inhibitor for fungal growth was found in extract of clove leaves. Therefore, clove leaves extract (anti fungi), liquid smoke of cashew nut shell (antibacteria) and leaffruit (antioxidant) may have potential to produce feed additives to substitute antibiotic growth promoters.

Key Words: Bioactive Substances, Herbals, Antioxidant, Antibacteria, Antifungi

\section{INTRODUCTION}

Feed additives are commonly used for animal production in aim to improve the productive performance, feed utilization efficiency and quality of animal products. One of the feed additives that widely used is antibiotic, known as antibiotic growth promoters (AGP). The AGP has been used since 1940's (Dibner $\underline{\&}$
Richards 2005) and legally recognized as feed additives in all over the world until 1970's when the Swann Reports 1969 showed the negative impact of the AGP usage such as the occurrence of microorganism resistant to antibiotics.

Since the Swann report, many countries banned or at least restricted the use of AGP. Indonesia also bans the use of AGP in animal feed as stated in the 
legislation Act 18/2009 juncto Act 41/2014. Endorsement of the regulation without precaution may deteriorate the poultry productivity and feed efficiency drastically. Therefore, it is important to find nonantibiotic feed additives to substitute for the AGP. On the other hand, many reports and opinion conclude that the use of AGP promote the occurrence of antibiotic resistant microorganisms which is harmful for the human.

Some efforts have been done in search of materials to replace the AGP which are "friendly" for environments and human health. Among them are enzymes, acidifiers, probiotic, prebiotic, plant bioactives and the combination of those products. As a tropical country, Indonesia has abundant of plants as source of plant bioactives. Some plants or herbs have been used traditionally as "healthy drinks" and for medications for human in Indonesia and elsewhere.

Bioactive compounds in plants are defined as compounds produced by plants having pharmacological or toxicological effects in man and animals (Bernhoft 2010). The typical bioactive compounds in plants are produced as secondary metabolites. Plant bioactives have been reported to have functions as antibiotic, anti fungi, antioxidant and immuno modulator. Some researches have been conducted in order to proof the beneficial effect of plant bioactives to replace AGP such as Aloe vera (Purwadaria et al. 2001; Bintang et al. 2001; Sinurat et al. 2003; Sinurat et al. 2004; Sinurat 2013), Curcuma longa and Curcuma xanthorrhiza (Samarasinghe et al. 2003; Sinurat et al. 2009), and guava leaves (Hoque et al. 2007; Kidaha et al. 2013). Most of the researches studied the effectivity of the bioactives obtained from single ingredient and the results have not been applied in the livestock industry commercially due to some factors such: variability on the effectivity, high production cost or too expensive when compared to the commercial AGP and when the use of AGP is still allowed in the country.

Synthetic antioxidants such as ethoxyquin, BHA (butylated hydroxyanisole) and BHT (butylated hydroxytoluene) are also used as feed additives in order to improve the healthyness (immunity of the animals). The plant antioxidant can induce the phase 2 enzymes or cytoprotective proteins in the cell and act to neutralize toxic agents when they appear (Blomhoff 2010). Farahat et al. (2016) reported that natural antioxidant obtained from decaffeinated green tea extract are effectively to enhance the immune response and vaccination potency in broilers without adversely affected the growth performance of broilers. The addition of antioxidant in feed may help the animal to 'fight' pathogen microorganisms.

In order to find an alternative to AGP, this research was focused on the searching of plants that contain bioactives effective for inhibiting bacteria growth, fungus growth and have high antioxidant activity. The combination of three bioactives obtained from plants are expected to form a feed additive that can replace or even better than antibiotic growth promoters.

\section{MATERIALS AND METHODS}

\section{Source of plant bioactives}

Twelve (12) plants which have been kown in literatures contain bioactives and have been used in society as traditional drinks or medications were used in this study, i.e.,: Binahong (Anredera cordifolia) leaves, clove (Syzygium aromaticum) leaves, guava (Psidium guajava) leaves, Mangosteen (Garcinia mangostana) fruit shell, Mimba (Azadirachta indica) leaves, Mindi (Melia azedarach L.) leaves, salam (Syzygium polyanthum) leaves, cashew nut shell, Sirih (Piper betle) leaves, meniran (Phyllanthus urinaria), kapok seed oil and lerak (Sapindus rarak) fruits. The characteristics of the plant bioactives used in the experiment were:

1. Salam (Syzygium polyanthum) leaves with bioactive components such as antioxidant, antiinflammation, antiallergy (Kusuma et al. 2011).

2. Binahong (Anredera cordifolia) leaves contain flavonoids which have antibacterial activity (Astuti et al. 2011).

3. Mimba (Azadirachta indica) leaves contain bioactive that effective as antibacteria, particularly against Vibrio cholerae (Thakurta et al. 2007).

4. Lerak (Sapindus rarak De Candole) fruits pericarp with high saponin contents and effectively inhibit growth of Escherichia coli (Astuti et al. 2009) and Eimeria tenella (Pasaribu et al. 2014).

5. Kapok (Ceiba pentandra) seed oil with high contents on cyclopropanoids which are effective to inhibit growth of Bacillus subtilis (Chekuboyina et al. 2012).

6. Guava (Psidium guajava) leaves contain tannin, tripertene, flavonoid, and have been reported to be effective as antioxidant and antimicrobes (Biswas et al. 2013).

7. Clove (Syzygium aromaticum) leaves are rich in eugenol which are effective as anti-fungi such as Fusarium oxysporum and anti-bacteria such as Pseudomonas solanacearum (Pandey \& Singh 2011).

8. Sirih (Piper betel) leaves contain hydroxychavicol, eugenol, which are effective as antiulcer, anthelmintic, antioxidant (Chakraborty \& Shah 2011).

9. Mindi (Melia azedarach L.) leaves contain terpenoid and azadirachtin (Meziane and Goumri, 2015) which are effective as antibacteria, antivirus, insectiside and as antioxidant (Khan et al. 2011). 
10. Mangosteen (Garcinia mangostana) fruit pericarp is rich in xanthones which are known as antioxidant, anti inflamation, antibacteria and antifungi (Palakawong et al. 2010). The ethanol extract have been reported effective to inhibit growth of pathogen bacteria that usually found in gastro intestinal tract such as Salmonella typhi, Shigella dysentriae, E. coli, Klebsiella pneumoniae, $V$. cholerae, Pseudo-monas aeruginosa and Staphylococcus aureus (Geetha et al. 2011).

11. Liquid smoke obtained from Cashew nut (Anacardium occidetale) shell contains phenols which are effective as antifungal and anti-microbial (Parasa et al. 2011). The liquid smoke has a low $\mathrm{pH}$ which may be effective to be used as an antimicrobial in feed (Saenab et al. 2016).

12. Gripeweed or leaffruit (Phyllanthus urinaria) plants commonly called chamber bitter or leafflower, is a herb species in the family Phyllanthaceae. The bioactives were reported as high antioxidant activities and effective as antibacteria (Kumaran \& Karanukaran 2007; Eldeen et al. 2010).

\section{Preparation of plant crude extract}

Samples of plant materials were dried and ground prior to extract. The samples were extracted by methanol for polar fraction or by hexane for non-polar fraction. Each $5 \mathrm{~g}$ of the sample was soaked in $10 \mathrm{ml}$ methanol solution. The soaking was performed with sonicator for 30 minutes. The solutions were then centrifuged for 15 minutes $(2500 \mathrm{rpm})$ and the supernatant was collected as a polar fraction.

Similar procedures were performed to obtain the extraction of the non-polar fraction by using hexane instead of methanol.

\section{Total phenol and tannin}

Phenol levels in the samples were measured by Folin-Ciocalteu method. Analyses were performed twice, i.e. before and after addition of polyvinyl polypyrrolidone (PVPP). The methods have been described by Makkar (2013)

\section{Analysis of antioxidant potential}

The antioxidant content of plant extraxts were determined following method as described by Shekar \& Anju (2014) The procedure in brief was as follows: 0.5 $\mathrm{g}$ of dried samples were diluted with $10 \mathrm{~mL}$ methanol. The solution $(1 \mathrm{~mL})$ were made in some different concentrations and each was reacted with $2 \mathrm{~mL} \mathrm{2,2}$ diphenyl-1-1-picrylhydrazil (DPPH) $0.2 \mathrm{mM}$. Then, they were incubated at room temperatures for 30 minutes. The assay was performed in dark room and the absorbance of the solution was measured at $517 \mathrm{~nm}$. Methanol was used as the blank $(1 \mathrm{~mL}$ methanol added with $2 \mathrm{~mL}$ DPPH $0.2 \mathrm{mM}$ ). Concentration to inhibit $50 \%$ oxidation, $\mathrm{ng} / \mathrm{mL}$ was calculated in each curve of extract concentration towards oxidative inhibitions.

$$
\% \text { DPPH inhibition }=\frac{\mathrm{A}-\mathrm{B}}{\mathrm{B}} \times 100 \%
$$

$A=$ Absorbance of control

$\mathrm{B}=$ Absorbance of sample

\section{Effectiveness to inhibit microorganism growth}

Two methods were performed in order to identify the effectiveness of the plant bioactives to inhibit the growth of microorganisms. The first method was the in vitro fermentation method or by measuring the total gas production. In this method, $0.1 \mathrm{~g}$ pepsin digested corn meal as substrate in the $15 \mathrm{ml}$ glass test tube, was added with $0.5 \mathrm{ml}$ plant extract and $10 \mathrm{~mL}$ artificial saliva buffer (McDougall buffer) which has been mixed with the chicken digesta as inoculum with ratio $4: 1$ to mimic gut's condition during fermentation.

The $\mathrm{CO}_{2}$ gas was ran for 15-20 minutes into the digesta-buffer prior to addition of the samples. After mixed homogenously and flushed with the $\mathrm{CO}_{2}$ gas, the tubes were tightly sealed and incubated at $37-40^{\circ} \mathrm{C}$ for 24 hours. Samples without plant extract were performed as negative control. The gas produced was measured every hour till 9 hours of fermentation and at the end of fermentation (24h). Total gas production was calculated as the sum of gas produced during $24 \mathrm{~h}$ of incubation. The amount difference between total gas production in the treated tubes and the control (without plant extract) were considered as the indicator on the effectiveness of the extract to inhibit microorganism growth. The higher the difference (or the less total gas production), the more effective the plant extract to inhibit the microorganism growth. Each treatment was replicated 4 (four) times.

The second method was by observing the growth of E. coli and Salmonella enteritidis in petri dish as described by Rollins \& Joseph (2000). Assays were performed by placing paper on the agar media inoculated with $E$. coli or $S$. enteritidis $s p$. The diameter of clear zone was measured as an indicator of effectiveness of the plant extract to inhibit the bacteria growth.

\section{Substrate preparation and source of microbes for inoculum}

Substrate was prepared as follows: $10 \mathrm{~g}$ corn meal was mixed with $300 \mathrm{ml}$ pepsin solution $(0.2 \%$ in $\mathrm{HCl}$ $0.1 \mathrm{~N}$ ). The mixture was incubated on water bath shaker at $40^{\circ} \mathrm{C}$ for 45 minutes followed by centrifugation at 
$3000 \mathrm{rpm}$ for 10 minutes. Then, the precipitate was washed with distilled water, and again centrifuged at $3000 \mathrm{rpm}$ for 5 minutes, dried and regarded as substrate for in vitro fermentation.

Source of microbes used for in vitro fermentation in this experiment was total microbes that present in the digesta of the chickens and were attacked by antibiotic growth promotors. The digesta were collected by squeezing the contents of the guts of chickens obtained from poultry slaughter house. The digesta were pooled and kept in the freezer and used as inoculum for in vitro fermentation.

\section{RESULTS AND DISCUSSION Identification of}

\section{plants \\ bioactive substances of some native}

Concentration of some bioactive compounds in some plants extract is shown in Table 1. Extract of clove leaves contain the highest total phenol $(6.04 \%)$ followed by the mangosteen fruit pericarp extract (4.76 $\%)$ as compared to other plant extracts. The kapok seed oil contained the lowest (not detected) total phenol. Similar to the total phenol content, the highest tannin levels was also found in clove leaf extract $(3.34 \%)$ followed by mangosteen fruit pericarp extract $(2.72 \%)$ and the lowest (not detected) in kapok seed oil. The tannin level in both clove leaf and mangosteen extract were found more than $50 \%$ of the total phenol. The saponin level, however, showed different trend. The highest saponin level was detected in $S$. rarak fruit pericarp extract $(59.71 \%)$ followed by liquid smoke of cashew nut shell $(50.46 \%)$ and the lowest level was found in kapok seed oil (1.19 \%). Total phenol, tannin and saponin are compounds that dissolved in polar solvents, therefore their content in kapok seed oil which dissolved in non polar solvent was very low compared to other plant extracts in this study.

Plant phenolic compounds and tannins are well known as potent antioxidant (Ghasemzadeh \& Ghasemzadeh 2011) and can serve as protectants against bacterial pathogen (Sytar et al. 2012). Plant saponin was also reported to inhibit sporulation of $E$. tenella oocysts (Pasaribu et al. 2011). Therefore, it is expected that the highest the content of the total phenol, tannin and saponin in the plants the higher the potential benefit for the consumers (animals).

Analyses on antioxidant activities of the samples were conducted in comparison with vitamin $\mathrm{C}$ (as standard) and the concentrations of plant extracts that effectively inhibit 50\% oxidation are shown in Table 2. The leaffruit (Phyllanthus urinaria) extract showed the least concentration $(124 \mu \mathrm{g} / \mathrm{mL})$ followed by clove leaves extract $(147.9 \mu \mathrm{g} / \mathrm{mL})$ and cashew nut liquid smoke $(156.5 \mu \mathrm{g} / \mathrm{mL})$. The antioxidant activity of

Table 1. Concentrations of total phenol, tannin and saponin in some plant extracts

\begin{tabular}{|c|c|c|c|c|c|}
\hline Plants name & Parts & $\begin{array}{l}\text { Method of } \\
\text { Process }\end{array}$ & $\begin{array}{c}\text { Total Phenol } \\
\text { (\% DM sample) }\end{array}$ & $\begin{array}{c}\text { Tannin } \\
(\%)\end{array}$ & $\begin{array}{l}\text { Saponin } \\
(\%)\end{array}$ \\
\hline Binahong (A. cordifolia) & Leaves & Extraction & 0.48 & 0.16 & 4.94 \\
\hline Clove (S. aromaticum) & Leaves & Extraction & 6.04 & 3.34 & 13.50 \\
\hline Guava $(P$. guajava $)$ & Leaves & Extraction & 3.34 & 2.30 & 5.70 \\
\hline Lerak ( S. rarak) & Fruit pericarp & Extraction & 0.24 & 0.05 & 59.71 \\
\hline Mangosteen (G. mangostana) & Fruit fruit pericarp & Extraction & 4.76 & 2.72 & 15.23 \\
\hline Leaffruit ( $P$. urinaria) & Whole plant & Extraction & 3.06 & 1.67 & 2.14 \\
\hline Cashew nut (A. occidetale) & Shell & Liquid smoke & $2.79 *$ & $1.42 *$ & $50.46^{*}$ \\
\hline Neem $($ A. indica) & Leaves & Extraction & 2.24 & 0.38 & 13.39 \\
\hline Mindi (M. azedarach & Leaves & Extraction & 0.94 & 0.34 & 16.29 \\
\hline Kapok (C. pentandra) & Seed oil & Screw pressed & ND & ND & 1.19 \\
\hline Salam (S. polyanthum) & Leaves & Extraction & 1.45 & 0.36 & 13.50 \\
\hline Sirih or betel plant (P. betle) & Leaves & Extraction & 3.18 & 2.30 & 6.88 \\
\hline
\end{tabular}

* Percentage in $100 \mathrm{ml}$ liquid smoke 
Table 2. Antioxidant activity of some plant extracts

\begin{tabular}{|c|c|c|}
\hline Plants name & Parts & Concentration to inhibit $50 \%$ oxidation, $\mathrm{ng} / \mathrm{mL}$ \\
\hline Binahong $(\text { A. cordifolia })^{*}$ & Leaves & ND \\
\hline Clove (S. aromaticum) & Leaves & 274.67 \\
\hline Guava $(P$. guajava) & Leaves & 625.95 \\
\hline Lerak (S. rarak) & Fruit pericarp & 6995.66 \\
\hline Mangosteen (G. mangostana) & Fruit pericarp & 338.42 \\
\hline Leaffruit $(P$. urinaria $)$ & Whole plant & 292.08 \\
\hline Cashew nut (A. occidetale) & Shell & 359.58 \\
\hline Neem (A. indica) & Leaves & 555.66 \\
\hline Mindi (M. azedarach & Leaves & NA \\
\hline Kapok (C. pentandra) & Seed oil & NA \\
\hline Salam (S. polyanthum) & Leaves & 759.72 \\
\hline Sirih or betel plant (P. betel) & Leaves & 532.52 \\
\hline
\end{tabular}

*The antioxidant activities of some plants were also correlated with antibiofilm activity (Gracia et al. 2017);

$\mathrm{ND}=$ not detected or no antioxidant activity; NA = not analysed

Binahong (A. cordifolia) leave extract, Mindi (M. azedarach) and Kapok (C. pentandra) seed oil could not be obtained since the green colour of binahong and mindi extract disturbed the color measurement during the analysis, while oil fraction of Kapok seed oil could not mix with the DPPH solution in the analysis. The least the concentration required to inhibit oxidation means the more effective the substances as antioxidant. Therefore, the leaffruit ( $P$. urinaria) extract and clove extract showed the best potential antioxidant activity.

Plant phenols are antioxidants by virtue of the hydrogen-donating properties of the phenolic hydroxyl groups (Blomhoff 2010). However, the results showed that the total phenol was not directly related to the antioxidant activity. As shown in Table 1, the highest total phenol was found in clove leaves extract (6.04\%), while the highest antioxidant activity was found in leaffruit extract (Table 2). Although, in general, samples with high antioxidant activities (leaffruit, clove leaves, and mangosteen fruit rind pulp) always contain high total phenols. The phenols have many sturctural component such as phenolic acids, flavonoids, stilbenes and lignans. The effectivity of each compound as antioxidant may be not the same and the level of each compound may different in different plants.

The effectiveness of the plant extracts to inhibit growth of microorganisms (in-vitro) was determined by volume of gas produced by microorganisms obtained from gastro intestinal tract of chickens during $24 \mathrm{~h}$. As shown in Table 3 the addition of antibiotic (50 ppm zinc bacitracin) or the plant extracts significantly $(\mathrm{P}<0.05)$ affected the amount of gas produced during the incubation. The gas production was significantly reduced by addition of the antibiotic (50 ppm zinc bacitracin) to $65 \%$ as compared to the control without antibiotic. Reduction of gas production to the level similar to antibiotic were found with addition of hexane extract of leaffruit ( $72 \%$ of control), kapok seed oil (69\% of control), and methanol extract of mangosteen fruit pericarp $(61.0 \%$ of control), clove leaves $(63 \%$ of control), S. polyanthum leaves (72\% of control), guava leaves (74\% of control) and M. azadirach leaves (77\% of control). If the reduction of total gas production can be used as indicator of the effectiveness to inhibit pathogen microorganisms, it could be concluded that these plant extracts are the best candidates to replace antibiotic. However, gas production in this method is the result of all microorganisms (obtained from chicken intestinal) including pathogens and non-pathogens. On the other hand, the purpose of this research was to explore the effectiveness of plant bioactives to inhibit growth of pathogen microorganisms which may be used as alternatives to AGP. Perhaps, gas production may only be used as a preliminary tool to indicate that the plant extract contains substances as anti-microorganism. The conventional method (diffusion test) by measuring the size of clear zone arround the samples place on an agar plate may still the best method to measure the effectiveness of a substance as an antibiotic.

Results of diffusion method to test the effectiveness of the plant extracts to inhibit growth of E. coli and $S$. enteritidis is presented in Table 4 . Negative control did not have a clear zone diameter $(0 \mathrm{~mm})$, but addition of antibiotic (pyripen $5.5 \mathrm{mg} / 10 \mathrm{ml}$ ) produced 
Table 3. In-vitro gas production of digested corn by microbes (obtained from chickens gastrointestinal tract) for $24 \mathrm{~h}$ as affected by plant extract addition

\begin{tabular}{|c|c|c|c|c|}
\hline \multirow[b]{2}{*}{ Plants' name } & \multicolumn{2}{|c|}{ Hexane fraction $(50 \mathrm{mg} / \mathrm{ml}$ extract $)$} & \multicolumn{2}{|c|}{ Methanol fraction $(50 \mathrm{mg} / \mathrm{ml}$ extract $)$} \\
\hline & $\begin{array}{l}\text { Total gas production, } \\
\mathrm{mL} / 24 \mathrm{~h}^{*}\end{array}$ & $\begin{array}{l}\text { Relative to } \\
\text { Control }\end{array}$ & $\begin{array}{l}\text { Total gas production, } \\
\mathrm{mL} / 24 \mathrm{~h}^{*}\end{array}$ & $\begin{array}{l}\text { Relative to } \\
\text { Control }\end{array}$ \\
\hline Binahong (A. cordifolia) & $24.63^{\mathrm{a}}$ & 0.95 & $20.35^{\mathrm{abc}}$ & 0.88 \\
\hline Clove (S. aromaticum) & $24.98^{\mathrm{a}}$ & 0.97 & $14.60^{\mathrm{d}}$ & 0.63 \\
\hline Guava (P. guajava) & $22.83^{\mathrm{ab}}$ & 0.88 & $17.08^{\mathrm{bcd}}$ & 0.74 \\
\hline Lerak (S. rarak) & $26.05^{\mathrm{a}}$ & 1.01 & $22.38^{\mathrm{ab}}$ & 0.97 \\
\hline Mangosteen (G.mangostana) & $22.67^{\mathrm{ab}}$ & 0.88 & $14.20^{\mathrm{d}}$ & 0.61 \\
\hline Leaffruit ( $P$. urinaria) & $18.7^{\mathrm{bc}}$ & 0.72 & ND & \\
\hline Cashew nut (A. occidetale) shell & $23.1^{\mathrm{ab}}$ & 0.89 & $17.5^{\mathrm{bcd}}$ & 0.75 \\
\hline Neem (A. indica) & $24.05^{\mathrm{a}}$ & 0.93 & $18.57^{\mathrm{abcd}}$ & 0.80 \\
\hline Mindi (M. azedarach) & $24.83^{\mathrm{a}}$ & 0.96 & $17.70^{\mathrm{bcd}}$ & 0.77 \\
\hline Kapok (C. pentandra) & $17.84^{\mathrm{bc}}$ & 0.69 & $20.60^{\mathrm{ab}} \mathrm{c}$ & 0.89 \\
\hline Salam (S. polyanthum) & $21.83^{\mathrm{abc}}$ & 0.84 & $16.73^{\text {cd }}$ & 0.72 \\
\hline Sirih or betel plant (P. betle) & $23.63^{\mathrm{a}}$ & 0.91 & $18.75^{\mathrm{acd}}$ & 0.81 \\
\hline Control (C) & $25.88^{\mathrm{a}}$ & 1.00 & $23.13^{\mathrm{a}}$ & 1.00 \\
\hline $\mathrm{C}+$ Zinc Bacitracin & $16.68^{\mathrm{c}}$ & 0.65 & $16.68^{\mathrm{c}}$ & 0.65 \\
\hline
\end{tabular}

* Different letters in superscripts showed significant different ( $\mathrm{p}<0.05)$; ND = Not determined; Control was not added with plant extracts.

significantly clear zone diameter. Not all the extracts produced clear zone (or ability to inhibit growth of $E$. coli or $S$. enteritidis). Almost all the methanol extract showed inhibition of $\mathrm{E}$. coli with different clear zone diameters except extracts of betel plant $(P$. betel) leaves, leaffruit ( $P$. urinaria), Salam ( $S$. polyanthum) and Neem (A. indica) leaves. However, only the hexane extraxt of kapok seed and $S$. rarak showed positive effect to inhibit $E$. coli. The most effective to inhibit $E$. coli, other than antibiotic was the methanol extract of $S$. rarak fruit $(2.05 \mathrm{~mm})$ followed by methanol extract of clove leaves $(1.98 \mathrm{~mm})$, methanol extract of cashew nut shell $(1.90 \mathrm{~mm})$ and liquid smoke of cashew nut shell $(1.2 \mathrm{~mm})$. The hexane extract showed only kapok seed oil and $S$. rarak fruit pericarp were slightly effective to inhibit $E$. coli growth, but hexane extract of mangosteen fruit pericarp, kapok seed, S. rarak fruit pericarp, guava leaves, A. cordifolia leaves, leaffruit, neem slightly inhibited the growth of $S$. enteritidis. In terms of effectiveness, methanol extracts which contain phenolic compounds and other polar bioactive compounds were more effective than hexane extracts to inhibit the growth of E. coli, while hexane extract which contain nonpolar bioactive compounds were more effective than methanol extracts to inhibit the growth of $S$. enteritidis. Both bacteria are Gram-negative and always found in digestive tracts, however, every species including their strains have been recognised differently sensitivity or resistency to antibacteria especially for those not included in broadspectrum. Some of E. coli strains and most $S$. enteritidis are pathogens. The bacteria used in this experiment was isolated from chicken digestive tract and pathogen, therefore the antibacteria activity detected in the plant extracts may prove the idea to replace the AGP with the plant extracts.

Inclusion of zinc bacitracin in the diet alter the microbiota composition in the ileum of broilers (Gong et al. 2008). Similar result was also reported by Engberg et al. (2000) which showed that addition of salinomycin or zinc bacitracin reduced the population of Clostridium perfringens and Lactobacillus salivarius in the intstinal of broilers.

Addition of anti-fungi (ketoconazole) showed effectively inhibit the growth of A. niger with the clear zone diameter $1.13-2.63 \mathrm{~cm}$. Almost all plant extracts tested were not effective to inhibit growth of fungi $(A$. niger BPT) as shown in Table 5. However, extract of Clove ( $S$. aromaticum) leaves and liquid smoke of Cashew nut (A. occidetale) shell were effective to inhibit the growth of the fungi. The clove leave meal extract showed the highest anti fungi activities with diameter of clear zone $1.24 \mathrm{~cm}$ and the liquid smoke of cashew nut shell with diameter of clear zone $1.18 \mathrm{~cm}$. 
Sinurat et al. Bioactive substances of some herbals and their effectiveness as antioxidant, antibacteria and antifungi

Table 4. Diameter (mm) of clear area on the culture of E. coli and S. enteritidis as affected by supplementation of plants extract

\begin{tabular}{|c|c|c|c|c|}
\hline \multirow{2}{*}{ Source of extracts } & \multicolumn{2}{|c|}{ Methanol extract } & \multicolumn{2}{|c|}{ Hexane extract } \\
\hline & E. coli & S. enteritidis & E. coli & S. enteritidis \\
\hline Negative control & $0^{\mathrm{f}}$ & $0^{\mathrm{c}}$ & 0 & 0 \\
\hline Positive control* & $3.16^{\mathrm{a}}$ & $3.05^{\mathrm{a}}$ & 2.28 & 2.9 \\
\hline Mangosteen (G. mangostana) & $1.77^{\mathrm{abc}}$ & $0^{\mathrm{c}}$ & - & 1.1 \\
\hline Betel plant (Piper betel) & $0^{\mathrm{f}}$ & $0^{\mathrm{c}}$ & - & - \\
\hline Clove (S. aromaticum) & $1.98^{\mathrm{ab}}$ & $0^{\mathrm{c}}$ & - & - \\
\hline Kapok (C. pentandra) & $1.63^{\mathrm{bcd}}$ & $0^{\mathrm{c}}$ & 1.13 & 1.05 \\
\hline Lerak (S. rarak) & $2.05^{\mathrm{ab}}$ & $0^{\mathrm{c}}$ & 1.1 & 1.1 \\
\hline Guava (P. guajava) & $1.23^{\mathrm{e}}$ & $0^{\mathrm{c}}$ & - & 1.1 \\
\hline Mindi (M. azedarach) & $1.20^{\mathrm{e}}$ & $0^{\mathrm{c}}$ & - & - \\
\hline $\begin{array}{l}\text { Cashew nut (A. occidetale) Shell hexane } \\
\text { extract }\end{array}$ & $1.90^{\mathrm{ab}}$ & $0^{\mathrm{c}}$ & - & - \\
\hline Binahong (A. cordifolia) & $1.40^{\mathrm{e}}$ & $0^{\mathrm{c}}$ & - & 1.1 \\
\hline Leaffruit $(P$. urinaria $)$ & $0^{\mathrm{f}}$ & $0^{\mathrm{c}}$ & - & 1.12 \\
\hline Salam (S. polyanthum) & $0^{\mathrm{f}}$ & $0^{\mathrm{c}}$ & - & - \\
\hline Neem $(A$. indica $)$ & $0^{\mathrm{f}}$ & $0^{\mathrm{c}}$ & - & 1.1 \\
\hline $\begin{array}{l}\text { Liquid smoke of Cashew nut (A. occidetale) } \\
\text { shell }\end{array}$ & $1.2^{\mathrm{ed}}$ & $1.15^{\mathrm{b}}$ & $1.2^{\mathrm{ed}}$ & $1.15^{\mathrm{b}}$ \\
\hline Significance $(\mathrm{P})$ & $<0.001$ & $<0.001$ & & \\
\hline
\end{tabular}

* antibiotic (pyripen $5.5 \mu \mathrm{g} / 10 \mathrm{ml}$ ) was added

Table 5. Diameter $(\mathrm{cm})$ of clear area on the culture of fungi ( A. niger BPT) as affected by supplementation of plants extract

Source of extract

Diameter of clear zone $(\mathrm{cm})$

\begin{tabular}{|c|c|c|}
\hline & Control + Ketoconazole & A. niger $\mathrm{BPT}$ \\
\hline Leaffruit $(P$. urinaria) plants & 1.13 & 0.00 \\
\hline Clove (S. aromaticum) leaves & 2.63 & 1.24 \\
\hline Neem $($ A. indica $)$ leaves & 1.40 & 0.00 \\
\hline Lerak (S. rarak) fruit & 1.27 & 0.00 \\
\hline Liquid smoke of Cashew nut (A. occidetale) shell & 1.23 & 1.18 \\
\hline Binahong (A. cordifolia) leaves & 1.20 & 0.00 \\
\hline Mindi (M. azedarach) leaves & 1.23 & 0.00 \\
\hline Kapok ( $C$. pentandra $)$ seed oil & 1.13 & 0.00 \\
\hline Betel plant (P. betel) leaves & 1.13 & 0.00 \\
\hline Salam (S. polyanthum) leaves & 1.13 & 0.00 \\
\hline Mangosteen (G. mangostana) & 1.17 & 0.00 \\
\hline Guava $(P$. guajava $)$ & 1.33 & 0.00 \\
\hline
\end{tabular}


The bioactive compounds in cloves leaf extract or oil are well known as eugenol (Yitbarek 2015). The eugenol has been used for medication purposes in human. Joseph \& Sujatha (2011) reported that the clove crude extract and the clove oil were effective to inhibit of some fungi such as Paeciliomyces, A. flavus, A. niger, Penicillium sp., Rhizopus sp. and Rhizomucor sp. Liquid smoke of cashew nut shell has low $\mathrm{pH}$ and contain many simple phenols (Saenab et al. 2016) that have the ability to depress the growth of bacteria and fungi.

\section{CONCLUSION}

Bioactive components such as total phenol, tannin and saponin of plant extract could not be used as an indicator of their effectiveness as antioxidant, antibacterial or antifungi, neither the ability to reduce the in vitro total gas production of microbes obtained from chicken's gut. The conventional method carried out to measure antioxidant activity, growth inhibition (of E. coli and S. enteritidis), and growth inhibition of fungi (A. niger) concluded that leaffruit extract, the liquid smoke of cashew nut shell and the clove leaves extract performed the highest potential as antioxidant, antibiotic and anti-fungi, respectively. Further study is required to prove if they could be used to substitute antibiotic growth promoters in feed.

\section{ACKNOWLEDGEMENT}

This study was funded by the Indonesian government (APBN 2015). The authors thank all the technicians (Mr. Helmy Hamid, Mrs. Emi Sujatmika, Mrs. Nila, Mrs. Eka) who helped in preparation of samples and doing laboratory analyses. We also express our appreciation to Claudia Clarence and Timotyus (Atma Jaya Catholic University of Indonesia) who took part in this research activity.

\section{REFERENCES}

Astuti DA, Wina E, Haryanto B, Suharti S. 2009. Performance and profile of some blood components of ongole crossbred cattle fed ration containing lerak (Sapindus rarak De Candole). Med Pet. 32:63-70.

Astuti SM, Sakinah M, Andayani R, Risch A. 2011. Determination of saponin compound from Anredera cordifolia (Ten) Steenis plant (binahong) to potential treatment for several diseases. J Agric Sci. 3:224-232.

Bernhoft A. 2010. A brief review on bioactive compounds in plants. In: Bernhoft A, editor. Bioactive compounds in plants - benefits and risks for man and animals. Oslo (Norwegia): The Norwegian Academy of Science and Letters. p. 11-17.
Bintang IAK, Sinurat AP, Purwadaria T. 2007. Penambahan ampas mengkudu sebagai senyawa bioaktif terhadap performans ayam broiler. JITV. 12:1-5.

Bintang IAK, Sinurat AP, Purwadaria T, Togatorop MH, Rosida J, Hamid H, Saulina. 2001. Pengaruh pemberian bioaktif dalam lidah buaya (Aloevera) terhadap penampilan ayam broiler. Bogor (Indones). Balai Penelitian Ternak.

Biswas B, Rogers K, McLaughlin F, Daniels D, Yadav A. 2013. Antimicrobial activities of leaf extracts of guava (Psidium guajava L.) on two gram-negative and grampositive bacteria. Int J Microbiol. 2013:1-7.

Blomhoff, R. 2010. Role of dietary phytochemicals in oxidative stress. In: Bernhoft A, editor. Bioactive compounds in plants - benefits and risks for man and animals. Oslo (Norwegia): The Norwegian Academy of Science and Letters. p. 52-70.

Chakraborty D, Shah B. 2011. Antimicrobial, anti-oxidative and anti-hemolytic activity of Piper betle leaf extracts. Int J Pharm Pharm Sci. 3:192-199.

Chekuboyina RK, Pagolu KR, Dadi BR, Nagala S, Rao R. 2012. Physico-chemical characterization and antimicrobial activity of Ceiba pentandra (Kapok) seed oil. Alter Med Stud. 2:43-47.

Colegate SM, Molyneux RJ. 2008. Bioactive natural products: detection, isolation, and structural determination. Boca Raton (USA): CRC Press.

Dibner JJ, Richards JD. 2005. Antibiotic growth promoters in agriculture: History and mode of action. Poult Sci. 84:634-643.

Farahat M, Abdallah F, Abdel-Hamid T, Hernandez-Santana A. 2016. Effect of supplementing broiler chicken diets with green tea extract on the growth performance, lipid profile, antioxidant status and immune response. $\mathrm{Br}$ Poult Sci. 57:714-722.

Ghasemzadeh A, Ghasemzadeh N. 2011. Flavonoids and phenolic acids: Role and biochemical activity in plants and human. J Med Plant Res. 5:6697-6703.

Geetha RV, Anitha R, Lakshmi T. 2011. Evaluation of antibacterial activity of fruit rind extract of Garcinia mangostana Linn on enteric pathogens-an in vitro study. Asian J Pharm Clin Res. 4:115-118.

Gong J, Yu H, Liu T, Gill JJ, Chambers JR, Wheatcroft R, Sabour PM. 2008. Effects of zinc bacitracin, bird age and access to range on bacterial microbiota in the ileum and caeca of broiler chickens. J Appl Microbiol. 104:1372-1382.

Gracia E, Magdalena S, Wina E, Sinurat AP, Purwadaria T. Plant extract activities as antioxidant and antibiofilm against chicken gut bacteria. JITV. 23:11-27.

Joseph B, Sujatha S. 2011. Bioactive compounds and its autochthonous microbial activities of extract and clove oil (Syzygium aromaticum L.) on some food borne pathogens. Asian J Bio Sci. 4:35-43. 
Kirakosyan A, Kaufman PB. 2009. Recent advances in plant biotechnology. New York (US): Springer.

Hoque MMD, Bari ML, Inatsu Y, Juneja VK, Kawamoto S. 2007. Antibacterial activity of guava (Psidium guajava L.) and neem (Azadirachta id/ca A. Juss.) extracts against foodborne pathogens and spoilage bacteria. Foodborne Path Dis. 4:481-488.

Joseph B, Sujatha S. 2011. Bioactive compounds and its autochthonous microbial activities of extract and clove oil (Syzygium aromaticum L.) on Some Food Borne Pathogens. Asian J Biol Sci. 4:35-43.

Khan AV, Ahmed QU, Mir MR, Shukla I, Khan AA. 2011. Antibacterial efficacy of the seed extracts of Melia azedarach against some hospital isolated human pathogenic bacteria strains. Asian Pac J Trop Biomol. 1:452-455.

Kidaha ML, Alakonya AE, Nyende AB. 2013. Bioactivity determination of methanol and water extracts for roots and leaves of Kenyan Psidium guajava L landraces against pathogenic bacteria. SpringerPlus. 2:670.

Kumaran A, Karanukaran RJ. 2007. In vitro antioxidant activities of methanol extracts of five Phyllanthus species from India. LWT Food Sci Tech. 40: 344-352.

Kusuma IW, Kuspradini H, Arung ET, Aryani F, Min YH, Kim JS, Kim YU. 2011. Biological activity and phytochemical analysis of three Indonesian medicinal plants, Murraya koenigii, Syzygium polyanthum and Zingiber purpurea. J Acupunct Meridian Stud. 4:75-79.

Meziane M, Goumri H. 2015. The antimicrobial effect of extracts of Melia azedarach on some pathogenic microorganisms. IJANS 3: 173-180.

Palakawong C, Sophanodora P, Pisuchpen S, Phongpaichit S. 2010. Antioxidant and antimicrobial activities of crude extracts from mangosteen (Garcinia mangostana L.) parts and some essential oils. Int Food Res J. 17:582589.

Pandey A, Singh P. 2011. Antibacterial activity of Syzigium aromaticum (clove) with metal ion effect against food borne pathogens. Asian J Plant Sci Res. 1:69-80.

Parasa LS, Tumati SR, Kumar LCA, Chigurupati SP, Rao GS. 2011. In-vitro antimicrobial activity of cashew (Anacardium occidentale L) nuts shell liquid against methicillin resistant Staphylococcus aureus (MRSA) clinical isolates. Int J Pharm Pharm Sci. 3:436-440.

Pasaribu T, Astuti DA, Wina E, Sumiati, Setiyono A. 2014. Saponin content of Sapindus rarak pericarp affected by particle size and type of solvent, its biological activity on Eimeria tenella Oocysts. Int J Poult Sci. 13:347-352.

Purwadaria T, Togatorop MH, Sinurat AP, Rosida J, Sitompul S, Hamid H, Pasaribu T. 2001. Identifikasi zat aktif beberapa tanaman (Lidah Buaya, Mimba dan Bangkudu) yang potensial. Bogor (Indones). Balai Penelitian Ternak.
Rollins DM, Joseph SW. 2000. Antibiotic disk susceptibilities. Maryland (USA): Department Cell Biology and Molecular Genetics, University of Maryland, College Park.

Rymer C, Huntington JA, William BA, Givens DI. 2005. In vitro cumulative gas production techniques: history, methodological considerations and challenges. Anim Feed Sci Tech. 123:9-30.

Saenab A, Wiryawan KG, Retnani Y, Wina E. 2016. Karakterisasi fisik dan kimiawi produk bioindustri cangkang biji jambu mete (Anacardium occidentale). J Littri. 22:81-90.

Samarasinghe K, Wenk C, Silva KFST, Gunasekera JMDM. 2003. Turmeric (Curcuma longa) root powder and mannaoligosacharides as alternatives to antibiotics in broiler chicken diets. Asian-Aust J Anim Sci. 16:14951500 .

Shekhar TC, Anju G. 2014. Antioxidant activity by DPPH radical scavenging method of Ageratum conyzoides Linn. leaves. Am J Ethnomed. 1:244-249.

Sinurat AP. 2013. Bioaktif tanaman lidah buaya sebagai imbuhan pakan unggas. In: Sumarno TD, Soedjana, Suradisastra K, editors. Membumikan Iptek Pertanian. Jakarta (Indones). IAARD Press.

Sinurat AP, Purwadaria T, Togatorop MH, Pasaribu T, Bintang IAK, Sitompul S, Rosida J. 2002. Respons ayam pedaging terhadap penambahan bioaktif tanaman lidah buaya dalam ransum: pengaruh berbagai bentuk dan dosis bioaktif lidah buaya terhadap performan ayam pedaging. JITV. 7:69-75.

Sinurat AP, Purwadaria T, Togatorop MH, Pasaribu T. 2003. Pemanfaatan bioaktif tanaman sebagai "feed additive" pada ternak unggas: Pengaruh pemberian gel lidah buaya atau ekstraknya dalam ransum terhadap penampilan ayam pedaging. JITV. 8:139-145.

Sinurat AP, Purwadaria T, Pasaribu T, Susana IWR, Dharma J, Rosida J, Sitompul S, Udjianto. 2004. Efektifitas bioaktif lidah buaya sebagai imbuhan pakan untuk ayam broiler yang diperoleh di atas litter. JITV. 9:145-150.

Sinurat AP, Purwadaria T, Bintang IAK, Ketaren PP, Bermawie N, Raharjo M, Rizal M. 2009. Pemanfatan kunyit dan temulawak sebagai imbuhan pakan untuk ayam broiler. JITV. 14:90-96.

Sytar O, Brestic M, Rai M, Shao H. 2012. Review: Plant phenolic compounds for food, pharmaceutical and cosmetics production. J Med Plants Res. 6:2526-2539.

Thakurta P, Bhowmik P, Mukherjee S, Hajra TK, Patra A, Bag PK. 2007. Antibacterial, antisecretory and antihemorrhagic activity of Azadirachta indica used to treat cholera and diarrhea in india. J Ethnopharmacol. 3:607-612. 
JITV Vol. 23 No 1 Th. 2018: 18-27

Tomlinson TR, Akerele O. 2015. Medicinal plants: their role in health and biodiversity. Pennsylvania (US): University of Pennsylvania Press.
Yitbarek MB. 2015. Phytogenics as feed additives in poultry production: a review. Int J Ext Res. 3:49-60. 